\title{
THE CORE-PERIPHERAL ORGANIZATION OF SOCIETY AND ADMINISTRATIVE-TERRITORIAL REFORM
}

\author{
Ihor PYLYPENKO \\ Kherson State University, Ukraine \\ pilipenko11@i.ua
}

\begin{abstract}
This thesis reveals the conceptual basics for geographical analysis of core-peripheral processes and structures along with the scientific and methodological basics of their spatial localization, parameterization, and formalization. The mechanisms of social and geographical peripheral formation in the context of dynamic regional management conceptions were explored. The major differences in the current socio-spatial processes in the center-peripheral structures were shown. Special attention is paid to the integral processes of centralization and peripheralization in the socio-spatial systems of different scales that determine the hierarchical order of the geographical objects multitude and play the role of a universal model, explaining the heterogeneity of geospace. The author proposes principles for applying basic provisions of the "core-periphery" concept during the administrative and territorial reform in Ukraine.
\end{abstract}

Key words: concept, core, periphery, centralization, peripheralization, administrative and territorial reform, geographical analysis.

UDC: $911.3(075.8)$

\section{ЦЕНТРО-ПЕРИФЕРІЙНА ОРГАНІЗАЦІЯ СУСПІЛЬСТВА ТА АДМІНІСТРАТИВНО-ТЕРИТОРІАЛЬНА РЕФОРМА}

\author{
Ігор ПИЛИПЕНКО \\ Херсонський державний університет, Україна \\ pilipenko11@i.ua
}

\begin{abstract}
Анотація: Розкрито концептуальні засади суспільно-географічного аналізу центро-периферійних процесів і структур, обґрунтовано науково-методичні методичні основи їх просторової локалізації, параметризації та формалізації. Виявлено механізми формування суспільно-географічних периферій в контексті динамічних концепцій регіонального розвитку, показано відмінності перебігу основних суспільно-просторових процесів у центро-периферійних структурах. Виділено інтегральні процеси централізації і периферізації суспільно-просторових комплексів різних масштабів, що зумовлюють ієрархічну впорядкованість множини географічних об'єктів і $є$ універсальною моделлю пояснення неоднорідність геопростору. Запропоновано принципи застосування базових положень концепції "центр-периферія" при проведені адміністративної та територіальної реформи в Україні.
\end{abstract}

Ключові слова: концепція, центр, периферія, централізація, периферізація, адмістративно-територіальна реформа, географічний аналіз.

Удк: 911.3(075.8)

Вступ. Постановка проблеми. Історичний досвід свідчить про нерівномірність соціальноекономічного, територіального розвитку країн і регіонів різного масштабу, об'єктивне існування географічних контрастів типу «центр - периферія». Існує i певна цілком універсальна циклічність подій, що впливають на виникнення, посилення або нівелювання цих контрастів. Явище поляризації всеохоплююче та ієрархічне: в процесі регіонального розвитку територіальна організація суспільства (ТОС) ускладнюється, відбувається поширення центро- периферійних процесів на всіх рівнях. Це зумовлює постійну увагу дослідників на питаннях теорії, методологіiі, методики дослідження центру та периферії як елементів геопростору та ТОС.

Перебудова соціально-економічного простору потребує швидких управлінських рішень, які б мали під собою міцну науково-практичну основу. Більшість сучасних програм розвитку регіонів та країни

(C) I. Пилипенко в цілому розглядають об’єкти управління (області, райони, міста) як прості симплекси, внутрішньо однорідні об'єкти. В той же час, просторова організація адміністративних одиниць навіть найнижчого рангу відзначається складністю, багатофункціональність, суттєвою внутрішньою диференціацією.

Сучасна загальна концепція державного управління повинна бути зорієнтована на вирішення об'єктивних проблем соціально-економічної нерівності, як в суспільному (соціальна стратифікація), так і просторовому аспектах. Оскільки держава визнає недостатній рівень інвентаризації власних ресурсів розвитку та засадами регіональної політики стимулює регіональні дослідження, то наукове вивчення центро-периферійних процесів та структур постає однією з актуальних задач суспільної географії, особливо зважаючи на недостатній рівень уваги 3 боку вітчизняних науковців щодо питань формування i розвитку периферії у широкому розумінні, а не тільки з огляду на процеси 
депресивності, властиві, як правило периферійним територіям.

Аналіз останніх досліджень та публікацій. 3 середини XX сторіччя використання понять центру, периферії, пошук мір центральності та периферійності, дослідження центро-периферійних відношень і зв'язків позначають майже кожне дослідження, тим чи іншим чином пов'язане $з$ пошуком регіональних відмін на всіх рівнях - локальному, регіональному, національному, глобальному. Найчастіше зміст відносин «центрпериферія» пов’язується 3 нерівномірністю розподілу по території функцій управління й відтворення інновацій, але в узагальненому вигляді мова йде про внутрішньодержавні контрасти будь-якого походження, адже кожне явище й кожний процес мають свої центр і периферію, зумовлені або рівнем розвитку явища (більше розвинутий центр і менш розвинена периферія), або місцем його походження (центр як місце зародження явища, «донор», периферія як «акцептор») (Пилипенко, 2015). Разом з тим відзначимо, що більшість досліджень все ж таки акцентують увагу на виявленні центрів та визначенні мір центральності, а периферія при цьому розглядається як додаток центру.

Питанням геопросторового розвитку присвячена значна кількість робіт не тільки в галузі географії, але і в економіці, політології, історії тощо. В їх числі роботи, присвячені загальним питанням просторового розвитку та його аналізу (зокрема, роботи Perroux F. (1950), Friedmann J. (1966), Pred A. (1966), Boudeville J. (1966), Hagerstrand T. (1968), Christaller W. (1966), ), Wallerstein I. (1974), Haggett P. (1975), Топчіева О.Г. (1988), Родомана Б.Б. (2007), Зубаревич Н. В. (2008), Lotfi S. (2011) тощо).

Відносини в системах типу «центр-регіони», «центр-периферія» докладно висвітлюються в працях Грицай О.В., Іоффе Г.В., Трейвіша А.Й. (1991), Руденко А.В. (2008), Borgatti S.P. (1999), Baldwin R. E.(2001), Copus A. (2001), Krugman P. (1991), Pociūtė G. (2014), Potter R. B. (2001), Raagmaa G. (2003), Wellhoffer S. (1988).

Формулювання цілей статті. Постановка завдання. Основною метою статті є запропонувати підходи до адміністративно-територіальної реформи (та адміністративного поділу) України на основі базових положень концепції «центр-периферія». Відповідно до мети роботи, завданнями статті виступають: аналіз наукових джерел, присвячених дослідженню просторових особливостей прояву концепції «центрпериферія»; концептуалізація базових положень цієї концепції та їх формалізація; сформулювати основні підходи та принципи щодо застосування базових положень концепції «центр-периферія» при проведенні адміністративно-територіальної реформи та вдосконаленні адміністративного устрою України.

Виклад основного матеріалу. Формування різних типів центро-периферійні структур відбувається внаслідок різноманіття суспільнопросторових процесів, що мають місце у територіальній організації суспільства, та об'єктивних закономірностей, їй притаманних. За узагальненням, проведеним Підгрушним Г.П. (2011), серед об'єктивних закономірностей, що визначають територіальну організацію суспільства, головними $\epsilon:$

1. Системно-синергетичний характер суспільного розвитку, який передбачає наявність у суспільно-територіальних комплексах та системах синергетичних ознак - емерджентності, неврівноваженості, чергування стійких та нестійких станів та етапів розвитку.

2. Стадійно-еволюційний характер розвитку суспільства, що проявляється у послідовній зміні окремих стадій, формацій, циклів та фаз розвитку як суспільства в цілому, так і окремих його компонентних та територіальних складових.

3. Ієрархічність суспільно-територіальних структур. В їі основі лежать відміни в масштабах розвитку та значимості функцій компонентів цих структур. Ця ієрархічність проявляється у «вертикальній» підпорядкованості та взаємообумовленості розвитку компонентів в складних суспільно-територіальних утвореннях. Така ієрархічність тісно пов'язана 3 дифузним характером територіального розвитку суспільства. При цьому будь-які інновації «переміщуються» від ядр вищого до ядр нижчого ієрархічного рівня, даючи їм нові імпульси розвитку.

4. Мультиплікативна обумовленість розвитку суспільно-територіальних систем. Вона пов'язана 3 примножуючим впливом окремих чинників та умов розвитку, що зумовлює формування поряд 3 системоформуючими компонентами низки інших доповнюючи, обслуговуючих, супутніх тощо. Цей механізм складає основу комплексного розвитку регіонів.

Наголосимо, що суспільно-географічна наука позиціонує своє бачення проблем дослідження периферії та периферійності 3 огляду на такі положення:

1. Периферія як територія за системноструктурними ознаками цілком відповідає визначенню географічного об'єкту, під яким розуміється (Алаєв, 1983) природне або антропогенного цілісне та відносно стабільне утворення в межах географічної оболонки, що характеризується певним географічним положенням та участю у формуванні або зміні геосистем. Зважаючи ж на наявність у більшості випадків суспільної компоненти у периферійних територіях, такі географічні об'єкти безумовно є об'єктами дослідження суспільно-географічної науки. Зауважимо, що периферійність як стан, відношення, фактор теж є об'єктом суспільногеографічного дослідження з огляду на значну участь суспільства у процесах поляризації геоверсуму.

2. Наявність центру та периферії фактично у будь-яких суспільних і територіальних явищах i процесах $\epsilon$ основою формування класичного предмету географічної науки - «відмін від місця до місця».

3. Периферія як територія і периферійність як властивість найбільш притаманні географічному простору, зважаючи на значну територіальну диференціацію перш за все природної основи життєдіяльності суспільства - природних умов 


\section{i ресурсів.}

4. Одна 3 фундаментальних суспільногеографічних категорій - категорія суспільногеографічного положення виявляється нерозривно пов'язаною 3 явищами поляризації географічного простору, наслідком яких і є формування периферій різних типів, генези, ієрархічних рівнів тощо.

5. Багато вимірність цих понять, наявність декількох змістових аспектів периферії та периферійності (в складових тріади «Природа Населення - Господарство») виставляє специфічні вимоги до суб'єктів досліджень, які на основі відповідної базової підготовки змогли б узагальнити та проаналізувати складні, багатоаспектні процеси суспільного розвитку. Саме географи з їх об'єктом дослідження «від геології до ідеології» спроможні виконати таке завдання.

Усвідомлення необхідності дослідження суспільно-географічних периферій спрямовує на визначення концептуальних основ, загальних методологічних орієнтирів аналізу центропериферійної організації геопростору загалом i окремих територій зокрема. Необхідне і власне визначення концепту периферії, оскільки академічний аналіз літературних, електронних джерел суспільно-географічної, політичної, соціальноекономічної інформації переконливо продемонстрував багатозначність у трактуванні понять центр, центральність, периферія, периферійність тощо.

Відправною точкою концептуального бачення систем типу «Центр-Периферія» можна вважати такі положення (Пилипенко, 2015):

1. «Центр-Периферія» - парне поняття, фундаментальна категорія, що характеризує ієрархічну впорядкованість множини географічних об'єктів і пояснює неоднорідність геопростору. Внутрішня (генетична) впорядкованість геопростору породжує ієрархію географічних об'єктів щодо їх просторової організації, отже, категорію «ЦентрПериферія» можна розглядати як міру ієрархічності геопростору.

2. Категорія «Центр-Периферія» має топологічну природу. Головна топологічна характеристика географічних об'єктів у геопросторі - місце. Геопростір - сума (інтеграл) місць. Диференціація місць породжує їх ієрархію, що знаходить свій вираз у центро-периферійній організації геопростору. Генетично Центр - перевага у системі місць, Периферія - недолік. Отже, Центр і Периферія у своїй основі топологічні.

3. Розвиток і взаємодія між Центром і Периферією здійснюється за законами самоорганізації і синергетики. Різниця місць географічних об'єктів породжує взаємодію між ними. За системною концепцією, це - процес самоорганізації множин географічних об'єктів, що проявляється в утворенні геосистем, геокомплексів. Отже, центро-периферійна організація геопростору - результат самоорганізації і міра його розвитку.

4. Генетично топологічна «Центр-Периферія» в процесі розвитку набуває метричних характеристик: первинні Центри і Периферії фіксують ріницю місцеположень, відображають міру впорядкованості та самоорганізації геопростору, а надалі змінюються внаслідок накладання метричних складових демографічних, інфраструктурних, економічних, соціальних потенціалів тощо.

5. Варто розрізняти Центр і Периферію базові (природні, геопросторові) та похідні (штучні, управлінські). Якщо перші є наслідком топологічної i, як наслідок, метричної неоднорідності i самоорганізації геопростору, то другі - результат суспільно свідомого надання центральних або периферійних функцій місцям 3 певними топологічними та метричними характеристиками. Зауважимо, що останній варіант у разі невідповідності штучних і природних Центрів і Периферій часто спричиняє необхідність посилення адміністрування і застосування спеціальних соціальних, економічних, політичних важелів управління.

6. Багаторівневість та ієрархічність геопростору породжує багаторівневість систем типу «ЦентрПериферія» i виникнення проблеми суперпозиції - накладання та співставлення функцій в місцях 3 певними топологічними, метричними i управлінськими характеристиками. Першоосновою виникнення такої проблеми є видова різноманітність Центрів і Периферій, насиченість геопростору різновидами відношень місцеположень. Процес такого співставлення може бути конструктивним i деструктивним, причому у разі конструктивної суперпозиції часто спостерігається синергетичний ефект у розвитку системи.

Авторське розуміння концепту периферії дозволяє визначити цей таксон як частину суспільного простору, в межах якого швидкість суспільно-географічних процесів мінімальна або їх вектор не співпадає 3 вектором розвитку ядер суспільного життя. Додамо, що до таких ядер відносяться перш за все великі та середні міста. Натомість, суспільно-географічний центр розуміється як частина суспільно-географічного регіону, яка має функціональні зв'язки зі своєю базою розвитку (перш за все, периферією) i, на відміну від інших частин регіону, виділяється суспільною атрактивністю, високою концентрацією суспільних процесів і явищ, які постійно ускладнюються. Крім того, важливою властивістю центру є відповідність його ознак спеціалізованим відрізняючим рисам (ознакам) геотаксонів або геосистем об'єктивного або суб'єктивного характеру.

Суспільно-географічний аналіз взаємозв'язків між центром i периферією дозволив відзначити наступне:

1. Центр формується під впливом сукупної взаємодії низки різнопланових факторів, виключно унікальних для кожної окремої території і сфери діяльності.

2. Як правило, існує тільки один (у конкретних соціально-економічних умовах) локалітет, де реалізація суспільних властивостей центра проявить себе максимально. Такий локалітет за умови 
поширення в його межах властивостей центру і $\epsilon$ периферією відповідного центру. Такий принцип формування периферій можемо охарактеризувати як принцип «унікальності місця».

3. Наступна реалізація цього принципу на різних ієрархічних рівнях (макро, мезо- і мікрорівні) призводить до вибору «практичного» локалітету, який, безумовно, прагне до заняття частини геопростору, максимально можливої за площею (знову підкреслимо - у специфічному природноекологічному, соціально-економічному середовищі).

Узагальнюючи характерні риси периферії як елементу геопросторової організації суспільства і базуючись на проведених автором дослідженнях, можемо конкретизувати такі основні специфічні функціональні відмінності у системі «центр периферія»:

1. Наявність кількісного та якісного (структурного) розриву між центром та периферією будь-якого рівня. Такий розрив пов'язаний 3 різночасовим та хвилеподібним розповсюдженням будь-яких інновацій.

2. Основна функціональна ознака периферії наявність окремих, ізольованих фізично (дистанційно) вогнищ суспільної діяльності, які пов'язані тільки iз зовнішніми центрами; Основний вид діяльності - експлуатація ресурсів, використовуваних як невідтворювальні (причому ресурсом $є$ й сама територія (площа), тому периферія може бути екстенсивно насичена).

3. Нескладна й фрагментарна соціальноекономічна i територіальна організація периферії: чітко простежується домінування в центрі диверсифікації суспільної структури, ускладнення соціально-економічних функцій та компонент, для периферії - симпліфікація, спрощення взаємозв'язків та взаємовідносин, як правило, за рахунок спрощення самої структури. Переважання відцентрових тенденцій впливу для центра та доцентрових для периферії: $є$ один характерний напрямок «центр - периферія».

4. Низький рівень суспільного освоєння (у широкому розумінні), низька насиченість елементами життєдіяльності суспільства, деконцентрація суспільної діяльності на периферії на противагу високій суспільній атракції центру, що проявляється концентрацією суспільних об'єктів, процесів та явищ. Вирішальним фактором територіальної диференціації цих процесів є відстань до центра.

5. Переважання в межах центру процесів інтеграції, посилення взаємозв'язків між географічними утвореннями та суспільними групами, а для периферії - переважання дезінтеграційних процесів, які призводять до послаблення зв'язків і, в деяких випадках, до повної самоізоляції периферійних утворень (наприклад, обезлюднення населених пунктів). Саме такі процеси, на наш погляд, спричиняють формування «периферійної» ментальності, яка ускладнює сприйняття інновацій, консервує застарілі суспільногеографічні відношення та зв'язки.

Здійснена нами систематизація i типізація центро-периферійних процесів i структур у територіальній організації суспільства показала, що: a) генетично варто розрізняти «Центр Периферію» базові (природні, геопросторові результат топологічної i, як наслідок, метричної неоднорідності і самоорганізації геопростору) та похідні (штучні, управлінські - результат суспільно свідомого надання центральних або периферійних функцій місцям 3 певними топологічними та метричними характеристиками);

б) за рівнями територіальної організації можна виділяти глобальну, макрорегіональні (в межах континентів), національні (державний), регіональні і локальні системи «Центр-Периферія»;

в) топологічна «Центр-Периферія» функціонує як точкова (місця), мережева (місця, поєднані комунікаціями), ареальна (сукупність місць, поєднана топологічно і метрично);

г) метрична (ознакова) «Центр-Периферія» формується як монофакторна або поліфакторна, що, відповідно, пояснює наявність компонентних (моновидових) та інтегральних Центрів і Периферій;

д) за способами формалізації Центр i Периферія можуть розглядатися як дискретні (дає змогу проводити систематику географічних об'єктів, регіонів, країн за рівнем центральностіпериферійності), так і континуальні (просторові), які характеризуються мірами центральності, поширенням зон впливу, градієнтами тощо;

е) за характером взаємодії, геопросторового поєднання в системі «центр-периферія» можна спостерігати різні варіанти переходу від геопросторових одиниць, що характеризуються центральними властивостями до периферійних територій і об'єктів: трендовий висхіднонисхідний поступовий перехід від інтенсивного до екстенсивного типу освоєння i розвитку; поляризовано-конфліктне геопросторове поєднання - відірваність, депересивність (протистояння); дифузивно-симбіотичне геопросторове поєднання - взаємодоповнення (наприклад, взаємовигідне існування міст і приміських зон).

На наш погляд, інтегральними, узагальнюючими суспільно-просторовими процесами в контексті дихотомії «центр - периферія» будуть виступати процеси централізації та периферізації, результатом яких буде набуття геопросторовими структурами властивостей центральності i периферійності i, власне, формування центрів і периферій як елементів геопростору.

Процес периферізації - суспільно-просторовий інтегральний процес, сутністю якого $є$ набрання периферійних властивостей регіонами. Результатом процесу $\epsilon$ формування суспільно-географічних периферій та консервування периферійних властивостей територій та регіонів.

Процеси периферізації супроводжуються також якісними змінами, зокрема відбувається еволюція спеціалізації периферії за такими напрямками:

1) «підтягування» до ядра периферійних територій (в цьому випадку відбувається надання периферії допоміжних та обслуговуючих функцій);

2) втрата ознак - зумовлює вибір нових функцій 
і іноді докорінні зміни спеціалізації;

3) у разі поглиблення спеціалізації створюються передумови соціально-економічного зростання, а периферійні території можуть ставати ядрами нових районів.

Зауважимо, що периферійні функції у територіальному поділі праці «розмазані» по континуально великій периферії. За периферією закріплюються функції виробництва товарів та послуг масового, повсякденного та часто безальтернативного споживання. Як правило, це призводить до низького територіального концентрування суспільних явищ та об'єктів в межах суспільно-географічних периферій. В свою чергу, низька концентрація не дозволяє сформуватися ядрам нового районоутворення.

В періоди криз ядра (центри), втрачаючи свої функції (або перебуваючи в стадії їі пошуку нових суспільних ролей) віддають часткову перевагу периферії за рахунок доступних і більш дешевих сировини, харчів, меншої земельної ренти, доступності елементарних ресурсів фізіологічного споживання і первинних соціальних потреб. Саме тому, в якості опосередкованих індикаторів кризових явищ в суспільстві можуть використовуватися параметри концентрації суспільних явищ (або комплексу явищ).

Параметризація

суспільно-просторового процесу периферізації як i інших інтегральних процесів полягає у визначені особливості динаміки розвитку (зміни станів). Основною категорією, що на всіх рівнях дослідження та рівнях регіоналізації в системі «Центр-Периферія» виступає в якості мірила контрастність («суспільно-географічний контраст»).

Якісний вимір процесу периферізації - мається на увазі посилення перцепційної, відчутної відміни (контрастності) між центром і периферією.

Кількісні вимір процесу периферізації - міра контрастів метризованих регіональних суспільних ознак. Таким чином, нарощування контрастів є наслідком процесів периферізації. На регіональному рівні ці процеси супроводжуються змінами кількісних параметрів суспільно-просторових процесів.

Вдосконалення АТУ країни та регіонів може стати дієвим організаційно-правовим шляхом вирішення проблеми зростаючих диспропорцій центро-периферійних відносин та поглиблення поляризації існуючих міжрегіональних та внутришньорегіональних диспропорцій. Існуючі адміністративні межі не відповідають реальним зонам впливу центрів та створюють штучні обмеження для їх розвитку. Застосування положень концепції «центр-периферії», в контексті реформування АТУ країни та регіонів повинно базуватися на наступних принципах, врахування яких сприятиме формуванню оптимальної схеми адміністративного поділу. Серед таких принципів слід відзначити наступні:

- визнання існування центрів та периферій як об'єктивного закону існування суспільного геопростору;

- сукупність факторів суспільно-географічного положення формує об'єктивно існуючі центри та периферії, розвиток яких тільки незначним чином корегується адміністративним статусом;

- зміна адміністративного устрою лише дещо знівелює просторові диспропорції за рахунок надання адміністративних функцій центрам нових адміністративних одиниць суспільно-географічних периферій;

- сформовані і існуючі суспільно-географічні центри повинні отримати просторові ресурси розвитку (за рахунок включення низових адміністративних одиниць до центрів);

- нові адміністративні одиниці, що виникають на базі АТО з центральними властивостями фактично являють собою нодальні (вузлові) мікрорайони, суспільно-географічні властивостіяких визначаються розвитком саме вузла (центра);

- нові адмінодиниці, які формуються у складі АТО 3 периферійними властивостями фактично являють собою гомогенні (однорідні) суспільногеографічні мікрорайони, тому обрання адміністративних центрів новостворених одиниць повинно враховувати чинник географічної центральності.

Проведене дослідження особливостей формування, відтворення i збереження центропериферійної організації геопростору дало змогу сформулювати такі висновки:

1. Закономірністю функціонування ієрархічних просторових структур типу «центр - периферія» $€$ збереження певної поляризації географічного та економічного простору, яка відтворюється незважаючи на застосування адміністративних, економічних, соціальних, політичних заходів 3 нівелювання регіональних контрастів.

2. Об'єктивні механізми відтворення центропериферійних контрастів і неминучості існування міжрегіональних i внутрірайонних диспропорцій мають три складові: природно-ресурсну, соціальноекономічну і соціально-психологічну (ментальну).

3. Соціально-економічний механізм, що полягає у дифузійному характері нововведень 3 їх «хвильовим» поширенням в межах окремих регіонів, є базовим, природно-ресурсний-відіграє вирішальну роль на перших етапах поляризації суспільного простору, а ментальний певним чином «консервує» периферійність. Акцентуємо, що з таких позицій, існування периферій різних типів у географічному просторі $\epsilon$ майже аксіоматичним, що дозволяє стверджувати про актуальність їх дослідження на всіх етапах розвитку суспільно-географічної науки.

4. Основні положення концепції «центрпериферія» можуть стати методологічною основою проведення реформи адміністративнотериторіального устрою. Ідеологія реформи повинна втратити ілюзії щодо соціально-економічного вирівнювання рівнів розвитку центральних та периферійних районів, а запропонувати механізми взаємовигідного розвитку таких різних, але діалектично єдиних складових геопростору. 


\section{References:}

1. Alaev È.B. Social'no-èkonomičeskâa geografiâ: ponâtijno-terminologičeskij slovar' [Socio-economic geography: conceptual and terminologic dictionary], Moscow, 1983, 350 p. (In Russian).

2. Baldwin R.E. Core-periphery model with forward-looking expectations. Regional Science and Urban Economics, 2001, N. 31, 2001, pp. 21-49.

3. Borgatti S. P., Stephen P., Everett M. G. Models of corer-periphery structures. Social Networks, 1999, N. 21, pp. 375-395.

4. Boudeville J. Problems of Regional Economic Planning. Edinburg, 1966,.p. 11.

5. Christaller W. Central Places in Southern Germany. Englewood Cliffs, N.J., 1966, 230 p.

6. Copus A. From core-periphery to polycentric development: Concepts of spatial and aspatial peripherality. European Planning Studies, 2001, Vol. 9, Iss. 1, pp. 539-552.

7. Friedmann J. Regional development policy. Boston: Mass. Inst. Techn., 1966, 279 p.

8. Gricaj O.V., Ioffe G.V., Trejviš A.I. Centr i periferiâ v regional'nom razvitii [The center and the periphery in regional development]. Moscow, 1991, 168 p. (In Russian)

9. Hagerstrand T. Innovation diffusion as a spatial process. Chicago: University of Chicago Press, 1968.

10. Hagget P. Geography: a modern synthesis. Harper International Edition, New York, London, 1975, 358 p.

11. Krugman P. Increasing returns and economic geography. Journal of Political Economy, 1991, N. 99, pp. 483499.

12. Latham A., McCormack D., McNamara Kim, McNeill D. Key Concepts in Human Geography: Key concepts in Urban geography. London: SAGE Publications Ltd, 2009, 234 p.

13. Mezencev K.V., Pìdgrušnij G.P., Mezenceva N.Ì. Regional'nij rozvitok v Ukrä̈ni: suspil'no-prostorova nerivnist' i polârizaciâ [Regional development in Ukraine: the socio-spatial inequality and polarization], Kyiv, 2014, 132 p. (In Ukrainian).

14. Naustdalslid J. A Multi-level Approach to the Study of Center-Periphery Systems and Socio-economic Change. Journal of Peace Research, 1977, N. 14 (3), pp. 203-222.

15. Perroux F. Economic space: theory and applications. Quarterly Journal of Economics, 1950, Vol. 64, pp. 20 32.

16. Pìdgrušnij G.P. Sutnìst' territorial'noï organìzaciï suspìl'stva iii zakonomìrnostì, procesi ta formi [The essence of the territorial organization of society: its laws, processes and forms]. Regional'nì problemi Ukraïni: geografičnij analiz ta pošuk šlâhivv virišennâ [Regional problems of Ukraine: geographical analysis and search for solutions], Kherson, 2011, pp. 253-259. (In Ukrainian).

17. Pociūtè G. Periferingumo teritorine raiška Lietuvoje: Daktaro disertacija Fiziniai mokslai, fizinè geografija. Vilnius, 2014. Access mode: http://vddb.library.lt/fedora/get/LT-eLABa-0001:E.02 2014 D_20140512_103814-60982/ DS.005.0.01.ETD

18. Potter R.B. Geography and Development: «Core and Periphery?» Area, 2001, Vol. 33, N. 4. pp. 422-427.

19. Pred A. R. The Spatial Dynamics of U.S. Urban-Industrial Growth. 1800-1914 / A. R. Pred. - Cambridge : MIT Prees, 1966.

20. Pilipenko İ.O., Gomanûk M.A., Mal'čikova D.S. Socìal'no-ekonomične ta socìologì̌ne obğruntuvannâ provedennâ admìnìstrativno-teritorìal'noï reformi oblasnogo region [Socio-economic and sociological study of administrative-territorial reform in a region]. Konstruktivna geografiâ: stanovlennâ, sučasnì dosâgnennâ ta perspektivi rozvitku [Constructive Geography: formation, modern achievements and prospects of development], 2006, pp. 118-120 (In Ukrainian)

21. Pilipenko I.O. Suspil'no-geografična periferiâ: koncepciâ, parametrizaciâ ì delìmitaciâa [Periphery in human geography: concept, parameterization and delimitation]. Kherson, 2015, 264 p. (In Ukrainian)

22. Raagmaa G. Centre-peripherymodel explaining the regional development of the informational and transitional society. 43rd Congress of the European regional science associahion (Jyväskylä, Finland, August 27-30, 2003). Access mode: http://www.jyu.fi/ersa2003/cdrom/papers/503.pdf

23. Rodoman B.B. Geografiâ, rajonirovanie, kartoidy [Geography, regionalization, kartoids]. Smolensk, 2007, 368 p. (In Russian)

24. Rudenko A.V. Sistema «centr-periferiâ» regiona (na primere Respubliki Tatarstan) [The system of "centerperiphery" of the region (on the example of the Republic of Tatarstan)]. Moscow, 2008, $21 \mathrm{p}$. (In Russian)

25. Scenarios on the territorial future of Europe. ESPON Project 3.2. Access mode: http://www.espon.eu/export/ sites/default/Documents/Publications/ESPON2006Publications/SpatialScenarios/espon3.2_60p._final_16-7-2007-c. pdf.

26. Smal' V.V. Transformaciâ gospodarstva postindustrial'nih kraïn: naukovì zasadi suspil'no- geografičnogo doslidžennâ [The transformation of post-industrial economy: scientific principles of human-geographical research]. Nizhyn, 2011, 370 p. (In Ukrainian).

27. Terlouw C. P. The Regional Geography of the World-system: External Arena, Periphery, Semiperiphery, Core. Koninklijk Nederlands Aardrijkskundig Genootschap, 1992, 232 p.

28. Topčiev A.G. Prostranstvennaâ organizaciâ geografičeskih kompleksov i system [The spatial organization of geographical complexes and systems], Kyiv-Odessa, 1988, 187 p. 
29. Wellhoffer S. E. Models of Core and Periphery Dynamics. Comparative Political Studies, 1988, Vol. 21,N 2 , 1988, pp. 281-307.

30. Williamson J. C. Regional inequality and the process of national development: a description of the patterns. Economic Development and Cultural Change, 1968, Vol. 13, N. 4, pp. 3-45.

31. Zubarevič N. V. Strategii prostranstvennogo razvitiâ v period èkonomičeskogo rosta [Spatial Development Strategy for the period of economic growth]. Vestnik Moskovskogo universiteta. Seriâ 5. Geografiâ. [Moscow University. Series 5. Geography]. 2008, Vol.1. pp. 51-57 (In Russian). 